\title{
KOMPETENSI PPL DAN KEMAMPUAN KELOMPOK TANI DALAM MENUNJANG BP3K BERPRESTASI DI KECAMATAN RAMAN UTARA KABUPATEN LAMPUNG TIMUR
}

\author{
(The Competence of Agricultural Extension Workers and Capabilities of Farmer Groups to Support The \\ Distinguished BP3K in North Raman Subdistrict of East Lampung)
}

Yohilda Elva Putri, Dewangga Nikmatullah, Begem Viantimala

Jurusan Agribisnis, Fakultas Pertanian, Universitas Lampung, Jl. Prof. Dr. Soemantri Brojonegoro No.1

Bandar Lampung 35141, Telp 082280603418,e-mail: yohildaelvaputri@gmail.com

\begin{abstract}
The research is to analyze competence of Agricultural Extension Workers (AEWs), ability of farmer groups, and analyze relationship between the AEWs' competence and the ability of farmer groups to support the distinguished North Raman BP3K. The research method used is a survey carried out in North Raman subdistrict of East Lampung. Data were collected in March - July 2017. The data are analyzed descriptively and using Kruskals Wallis test. Respondents are 77 people consisting of three AEWs' and 74 rice farmers in North Raman subdistrict specified using a purposive sampling method. The results showed the Competence of the AEW' is in medium category and the ability of farmer groups is in medium category. There is relationship between the competence of the AEW's and the ability of farmer groups to support the distinguished BP3K in North Raman subdistrict.
\end{abstract}

Key words: AEWs' Competence, BP3K, farmer groups' capability

\section{PENDAHULUAN}

Pembangunan pertanian berkaitan dengan upaya peningkatan kesejahteraan petani dan menanggulangi kemiskinan khususnya di pedesaan. Penyuluhan menjadi sarana kebijakan yang efektif untuk mendorong pembangunan pertanian, dalam situasi petani tidak mampu mencapai tujuannya karena keterbatasan pengetahuan dan wawasan. Agar petani dapat melakukan praktik-praktik yang mendukung usahatani, maka petani membutuhkan informasi inovasi di bidang pertanian. Informasi dapat diperoleh petani dari penyuluh melalui penyelenggaraan kegiatan penyuluhan pertanian. Kegiatan penyuluhan dalam pembangunan pertanian berperan sebagai jembatan yang menghubungkan antara praktik yang dijalankan oleh petani dengan pengetahuan dan teknologi petani yang selalu berkembang menjadi kebutuhan para petani (Kartasapoetra 1994).

Tugas dan peran para penyuluh pertanian sebagai jembatan penghubung informasi pertanian kepada petani. Para penyuluh mempunyai peran strategis dalam pencapaian kesuksesan pembangunan pertanian. Informasi pertanian menjadi salah satu faktor kunci dalam pencapaian keberhasilan program pembangunan pertanian tak dapat dipungkiri. Selama ini informasi pertanian terkesan lamban sampai ke daerah, sehingga produktivitas pertanian juga lamban mengalami peningkatannya. Keberhasilan program penyuluhan pertanian dapat tercapai apabila didukung oleh Penyuluh Pertanian yang profesional, kreatif, inovatif, dan berwawasan global dalam bidang penyuluhan dan agribisnis (Sitompul 2014). Kompetensi penyuluh pertanian lapangan adalah Kemampuan untuk melaksanakan tugas-tugas secara efektif, dan profesional yaitu tingkat keahlian atau keterampilan yang didasarkan di dalam menjalankan tuntutan tugas atau profesinya (Imran dan Ganang 1999).

Menurut Kementerian Pertanian (2014), permasalahan pembangunan pertanian Indonesia meliputi permasalahn lahan pertanian, infastruktur, benih, regulasi atau kelembagaan, permodalan dan sumber daya manusia (SDM). Salah satu permasalahan dalam hal SDM adalah keterbatasan tenaga penyuluh pertanian baik dari segi kuantitas maupun kualitasnya. Oleh karena itu, arah kebijakan pembangunan pertanian tahun 20152019 yang dirumuskan untuk mengatasi permasalahan tersebut ialah dengan meningkatkan kuantitas dan kualitas kinerja penyuluh pertanian Adanya kompetensi penyuluh pertanian lapang (PPL) yang tinggi akan meningkatkan kinerja PPL dalam melaksanakan program - program yang ada di BP3K termasuk didalamnya dapat meningkatkan kemampuan kelompoktani binaan PPL yang bersangkutan. 
BP3K Raman Utara merupakan BP3K yang berhasil memperoleh penghargaan berupa BP3K Berprestasi Tingkat Provinsi Lampung tahun 2015. BP3K Berpresatasi merupakan penghargaan yang diberikan oleh pemerintah kepada BP3K Raman Utara yang berhasil dalam melaksanakan kegiatan penyuluhan diwilayah kerjanya. Pencapaian BP3K Berprestasi Tingkat Provinsi Lampung Tahun 2015 diukur dengan 4 aspek yaitu sarana dan prasarana, sumber daya manusia, manajemen oprasional, dan aktivitas.

Keberhasilan BP3K Raman Utara dalam memperoleh penghargaan berupa BP3K Berprestasi tentunya tidak lepas dari kinerja penyuluh dan kompetensi PPL yang ada di BP3K Raman Utara tersebut. Oleh karena itu kegiatan kompetensi Penyuluh Pertanian Lapang dan kemampuan kelompoktani dalam menunjang BP3K Berprestasi memilih untuk diteliti. Tujuan penelitian ini adalah untuk mengetahui kompetensi Penyuluh Pertanian Lapang (PPL) serta kemampuan kelompoktani dan Hubungan antara kompetensi Penyuluh Pertanian Lapang (PPL) dengan kemampuan kelompoktani dalam menunjang BP3K Berprestasi di Kecamatan Raman Utara.

\section{METODE PENELITIAN}

Metode yang digunakan dalam penelitian ini adalah metode survei. Penelitian ini dilakukan di Kecamatan Raman Utara Kabupaten Lampung Timur. Penentuan sampel dilakukan secara acak sederhana (simple random sampling). Sampel pada penelitian ini yaitu PPL yang berjumlah 3 orang di karena pada penelitian ini hanya mengambil 3 desa, dan anggota kelompoktani 74 orang. Perhitungan penentuan jumlah sampel berdasarkan teori Sugiarto, Siagian, Sunaryanto, dan Oetomo (2003) yaitu:

$\mathrm{n}=\frac{\mathrm{Ni}}{\mathrm{N}} \times \mathrm{ni}$

Keterangan :

ni $=$ Jumlah sampel petani menurut wilayah binaan penyuluhan pertanian

$\mathrm{n}=$ Jumlah sampel petani keseluruhan

$\mathrm{N}=$ Jumlah populasi petani keseluruhan

$\mathrm{Ni}=$ Jumlah populasi petani menurut wilayah binaan

Sampel yang diperoleh dari penggunaan rumus diatas diperoleh 32 orang responden sampel di
Desa Rejo Binangun, 21 orang responden sampel Desa Raman Fajar, 21 orang responden sampel Desa Rukti Sediyo. Data yang digunakan dalam penelitian ini meliputi data primer dan data sekunder.

Pengumpulan data penelitian ini dilakukan dan bulan Mei-Juni 2017. Metode analisis data yang digunakan untuk menganalisis kompetensi PPL dan kemampuan kelompoktani dalam menunjang BP3K Berprestasi digunakan metode deskriptif dan untuk metode analisis hubungan kompetensi PPL dan kemampuan kelompoktani dalam menunjang BP3K Berprestasi yaitu dengan statistika non parametrik uji Kruskal Wallis (Siegel 1986) sebagai berikut :

$\mathrm{H}=\frac{12}{\mathrm{~N}(\mathrm{~N}+1)} \sum_{\mathrm{i}=1}^{\mathrm{k}} \frac{\mathrm{R}_{\mathrm{i}}^{2}}{\mathrm{n}_{1}}-3(\mathrm{~N}+1)$

Keterangan :

$\mathrm{k}=$ Banyaknya sampel

$\mathrm{ni}_{\mathrm{i}}=$ Banyaknya kasus sampel ke-i

$\mathrm{N}=\Sigma$ ni = banyaknya seluruh kasus

$\mathrm{Ri}^{2}=$ Total rangking untuk setiap sampel ke-i

$\Sigma^{\mathrm{k}}{ }_{\mathrm{i}=1}=$ Menunjukkan penjumlahan seluruh $\mathrm{k}$ sampel (kolom-kolom) mendekati distribusi Chi square dengan $\mathrm{db}=\mathrm{k}-1$ untuk ukuran-ukuran sampel besar $n$ yang cukup besar

Kaidah pengambilan keputusan adalah :

1. Jika nilai sig $\geq 0,05$ maka tidak ada hubungan antara variabel $Y$ dengan variabel $X$.

2. Jika nilai sig $\leq 0,05$ maka terdapat hubungan antara variabel $Y$ dengan variabel $X$.

\section{HASIL DAN PEMBAHASAN}

\section{Karakteristik Responden}

BP3K Raman Utara merupakan BP3K di Kecamatan Raman Utara Kabupaten Lampung Timur. Instansi ini berkedudukan di Desa Rejo Binangun Kecamatan Raman Utara Kabupaten Lampung Timur Provinsi Lampung. Kecamatan Raman Utara merupakan daerah dengan bentuk wilayah berombak sampai berbukit.Kecamatan Raman Utara berpenduduk 36.049 jiwa yang terdiri dari penduduk laki - laki sebanyak 18.406 jiwa dan penduduk perempuan sebanyak 17.643 jiwa, dengan luas wilayah $90,58 \mathrm{Km}^{2}$. 


\section{Kompetensi PPL (Variabel X)}

Kompetensi penyuluh pertanian lapangan (X) adalah kemampuan berpikir, bersikap, dan bertindak yang mendasari dan merefleksikan wujud perilaku dan kinerja seseorang dalam aktivitas di bidang pekerjaannya. Menurut Yoder (1999) dalam Handayani (2015) menunjukkan bahwa para penyuluh di negara sedang berkembang perlu menguasai kompetensi professional yang mencakup bidang: administrasi, perencanaan, pelaksanan dan evaluasi program, komunikasi, metode-metode pengajaran dan penyuluhan, pemahaman terhadap tingkah laku manusia, dan pemeliharaan profesionalisme. Penelitian ini mengacu pada 8 indikator menurut Yoder (1999) dalam Handayani (2015) terdiri dari. Hasil penelitian kompetensi PPL pada penelitian ini dapat dilihat pada Tabel 1.

\section{A. Kompetensi Administrasi}

Kompetensi administrasi adalah kompetensi dasar dalam mengelola data pelaksanaan sistem penyuluhan yang meliputi komunikasi, kerja dan manusia. Kompetensi administrasi adalah tingkat kemampuan yang mencakup aktivitas didalam merumuskan tujuan nyata program, mengelola waktu secara efektif dan kerjasama antar staf. Kompetensi administrasi PPL di BP3K Raman Utara dapat dilihat pada Tabel 1. Berdasarkan Tabel 1 terdapat bahwa kompetensi administrasi PPL termasuk ke dalam klasifikasi tinggi yang berarti kemampuan penyuluh dalam merumuskan tujuan nyata orientasi bagi kerjasama antar staf berjalan dengan baik, adanya saling tolong menolong antar penyuluh lainnya, dan pengelolaan waktu secara efektif.

Tabel 1. Rekapitulasi Kompetensi Profesional Penyuluhan Pertanian Lapang di BP3K Raman Utara

\begin{tabular}{|c|c|c|c|}
\hline No & Indikator & $\begin{array}{c}\text { Rata-rata } \\
\text { skor }\end{array}$ & Kategori \\
\hline 1. & Kompetensi Administrasi & 6,181 & Tinggi \\
\hline 2. & $\begin{array}{l}\text { Kompetensi Perencanaan } \\
\text { Program }\end{array}$ & 7,727 & Sedang \\
\hline 3. & $\begin{array}{l}\text { Kompetensi Pelaksanaan } \\
\text { Program }\end{array}$ & 7,181 & Sedang \\
\hline 4. & Kompetensi Pengajaran & 5,090 & Sedang \\
\hline 5. & Kompetensi Komunikasi & 3,090 & Sedang \\
\hline 6. & $\begin{array}{l}\text { Kompetensi Pemahaman } \\
\text { Prilaku Manusia }\end{array}$ & 6,181 & Rendah \\
\hline 7. & $\begin{array}{l}\text { Kompetensi Memelihara } \\
\text { Profesionalisme }\end{array}$ & 4,636 & Sedang \\
\hline 8. & Kompetensi Evaluasi & 4,090 & Sedang \\
\hline & Tingkat Kompetensi & & Sedang \\
\hline
\end{tabular}

\section{B. Kompetensi perencanaan program}

Kompetensi perencanaan program adalah suatu cara bagaimana mencapai tujuan sebaik-baiknya dengan sumber-sumber yang ada supaya lebih efisien dan efektif, perencanaan program penyuluhan memberikan kerangka kerja bagi penyuluh dan semua pihak yang terlibat (termasuk petani) untuk mengambil keputusan tentang kegiatan-kegiatan yang dilaksanakan demi tercapainnya tujuan pembangunan.

Berdasarkan pada Tabel 1 tampak bahwa kompetensi perencanaan program termasuk dalam kategori sedang yang menunjukkan bahwa kemampuan penyuluh dalam merencanakan program penyuluhan kurang baik. karena adanya wilayah binaan yang cukup jauh untuk ditempuh oleh seorang penyuluh dalam melakukan perencanaan program.

Keberhasilan suatu kegiatan penyuluhan menurut Yoder (1999) dalam Maulina (2015) akan sangat tergantung dari dilaksanakannya kegiatan perencanaan program dengan baik. Semakin kegiatan perencanaan program dilaksanakan dengan baik, maka akan lebih mendorong berhasilnya suatu kegiatan penyuluhan.

\section{Kompetensi Pelaksanaan Program}

Kompetensi pelaksanaan program penyuluhan pertanian dilakukan harus sesuai dengan program penyuluhan pertanian. Berdasarkan pada Tabel 1 tampak bahwa kompetensi pelaksanaan program termasuk dalam kategori sedang. Program penyuluhan pertanian yang dimaksud untuk memberikan pedoman, dan sebagai alat pengendalian pencapaian tujuan penyelenggaraan penyuluhan pertanian. Perencanaan dan pelaksanaan program, pengembangan hubungan kerjasama dengan sasaran (client), penggunaan ragam teknik di dalam mempengaruhi sasaran penyuluh cukup baik.Karena sebagian petani masih kurang wawasan dan percayadiri pada diri petani untuk lebih maju dalam pencapaian sebuah tujuan program.

Hal ini tidak sejalan dengan hasil penelitian Santi (2016), diketahui bahwa tingkat kinerja penyuluh pertanian di BP3K Kecamatan Gadingrejo pada indikator pelaksanaan penyuluhan pertanian termasuk dalam klasifikasi rendah. Hal tersebut dikarenakan penyuluh pertanian hanya rajin mengunjungi kelompok tani yang aktif saja dan pada saat akan dilakukan penyuluhan dalam bentuk 
demonstrasi, sekolah lapang, temu teknis dan kursus tani biasanya penyuluh pertanian akan merekomendasikan kelompok tani yang aktif tersebut. Selain itu,penyuluh pertanian jarang memberikan informasi, jarang membangun kerja sama, jarang membangun kemitraan dan jarang memandu petani binaan membuat proposal. Berdasarkan hasil penelitian, hanya 1 (satu) kelompok tani yang telah menjalin kemitraan melalui program kredit ketahanan pangan dan energi (KKPE) dengan Bank Rakyat Indonesia (BRI).

\section{Kompetensi Pengajaran}

Kompetensi pengajaran adalah suatu proses atau aktivitas yang memerlukan rancangan, pelaksanaan penilaian yang bertujuan untuk menyebarkan ilmu pengetahuan atau kemahiran tertentu. Pada Tabel 1 tampak bahwa kompetensi pengajaran termasuk dalam kategori sedang. Hal ini dapat dilihat dari indikator menyusun materi penyuluhan pertanian dan menerapkan metode penyuluhan sedang dikarenakan kemampuan mengajar penyuluh dalam menyampaikan informasi penyuluhan kurang dipahami oleh petani. Karena aspek terpenting dalam pelaksanaan pengajaran pendidikan orang dewasa khususnya terhadap petani dalam kegiatan penyuluhan (pengajaran) adalah konsep dalam pendekatan belajar orang dewasa antara lain konsep belajar learning by doing.

\section{E. Kompetensi komunikasi}

Kompetensi Komunikasi sangat diperlukan karena manusia berinteraksi dengan manusia lain melalui komunikasi. Komunikasi merupakan proses penyampaiaan pesan oleh seseorang kepada orang lain untuk memberi tahu, mengubah sikap, pendapat atau perilaku baik secara lisan (langsung) ataupun tidak langsung (melalui media) kompetensi komunikasi yaitu kemampuan yang mencakup kemampuan membangun komunikasi diantara staf dan sasaran, dan kompetensi menyiapkan publikasi dan penggunaan alat komunikasi.

Berdasarkan pada Tabel 1 tampak bahwa kompetensi komunikasi termasuk dalam kategori sedang. dapat dilihat dari indikator menyiapkan publikasi dan penggunaan alat komunikasi penyuluh cukup baik dalam mengaplikasikan alat teknologi dan pada indikator membangun komunikasi antar staf dan sasaran penyuluh juga cukup baik sehingga mudah dipahami oleh staf maupun sasaran penyuluh (petani). Kegiatan yang harus diperhatikan oleh penyuluh untuk tercapainya suatu kegiatan penyuluhan yang berhasil adalah komunikasi, karena merupakan proses penyampaian pesan dari penyuluh kepada petani atau klien sebagai sasaran penyuluhan, maka penyuluh harus memperhatikan aspek-aspek yang mempengaruhi tingkat ketepatan untuk tercapainya komunikasi yang efektif.

Hal ini tidak sejalan dengan penelitian Diqa (2017) bahwa Penyuluh belum memfasilitasi pengembangan media untuk penyebaran informasi karena keterbatasan media informasi yang ada, namun disisi lain disebabkan tidak adanya inisiatif bagi petani untuk membuat media yang dapat dijadikan sumber informasi bagi anggotanya, petani hanya mengandalkan penyuluh untuk memperoleh informasi, selain itu informasi yang diberikan oleh penyuluh dalam kegiatan penyuluhan pertanian tidak cukup untuk mengubah sikap, menambah pengetahuan dan keterampilan petani, karena sumberdaya petani yang rendah sehingga sulit mengadopsi inovasi dan keterbatasan media informasi yang ada.

\section{F. Kompetesi Pemahaman Perilaku Manusia}

Kompetesi pemahaman perilaku manusia adalah kemampuan yang mencakup menilai persepsi sosial. Berdasarkan pada Tabel 1 tampak bahwa kompetensi pemahaman prilaku manusia termasuk dalam kategori rendah. Persepsi sosial, mengenal budaya setempat, mengenal perbedaan belajar dan mengindetifikasi perilaku sosial, dan mengindentifikasi kelompok kurang baik. karenakan sebagian penyuluh di kecamatan Raman Utara masih kurangnya bersosalisasi sesama kelompoktaninya sehingga penyuluh belum bisa mahami perilaku sasaran dengan baik sehingga sebagian tujuan program belum terlaksanakan.

\section{G. Kompetensi Memelihara Profesionalisme}

Kompetensi memelihara profesionalisme adalah kemampuan yang mencakup mengidentifikasi peluang untuk meningkatkan profesionalisme. penyuluh sudah mulai optimal dalam pencapaian kompetensi Penyuluh Pertanian Lapang dalam memelihara tingkat profesionalismenya. Berdasarkan pada Tabel 1 tampak bahwa memelihara profesionalisme termasuk dalam kategori sedang. Karena sebagian penyuluh sudah belajar secara mandiri untuk kebutuhan profesinya dan sebagian petani merespon dengan cukup baik. Penyuluh harus mampu untuk memelihara dan 
meningkatkan kualitas profesionalismenya. peningkatan profesionalisme penyuluh dapat dilakukan dengan cara memiliki jejaring kerja dengan lembaga-lembaga penyedia informasi dan teknologi seperti lembaga penelitian dan perguruan tinggi, serta memberikan fasilitas berupa komputer dan akses internet untuk dapat berkomunikasi dengan lembaga-lembaga penyedia informasi dan teknologi tersebut.

\section{H. Kompetensi Evaluasi}

Kompetensi evaluasi adalah proses penentuan apakah materi dan metode pembelajaran telah sesuai dengan tujuan yang diharapkan. Penentuan bisa dilakukan salah satunya dengan cara pemberian tes kepada sasaran/pembelajar.

Berdasarkan pada Tabel 1 tampak bahwa kompetensi evaluasi termasuk dalam kategori sedang. Bahwa Penyuluh dalam mengevaluasi berdasarkan semua aspek sesuai dengan wilayah kerja. hasil evaluasi pelaksanaan penyuluhan pertanian disusun dalam bentuk laporan. Penyuluhan sudah mendapatkan pelatihan tentang materi evaluasi program penyuluhan tahun 2014 yang dilaksanakan pada tanggal 8 desember 2014 oleh BP3K Raman Utara. Hal ini mencerminkan keadaan kompetensi penyuluh dalam hal evaluasi sudah baik. Kompetensi yang dimiliki penyuluh tergolong cukup baik dapat dilihat bahwa sebagian besar dari penyuluh sudah memiliki kemampuan untuk melaksanakan tugas atau tuntutan profesinya secara evektif dalam menjalankan setiap program penyuluhan.

\section{Kemampuan Kelompoktani (Y)}

Kemampuan kelompoktani (Y) adalah kapasitas/kompetensi yang dimiliki kelompoktani dalam menjalankan funsinya diukur melalui tiga indikator yang merujuk pada Peraturan Menteri Pertanian Nomor 82/Permentan/OT.140/9/2013 Tentang Pedoman Pembinaan Kelompok Tani dan Gabungan Kelompok Tani yaitu kelas belajar, wahana kerja sama, dan unit produksi. Kemampuan kelompoktani di BP3K Raman Utara berdasarkan masing masing indikator dapat dilihat pada Tabel 2.

\section{A. Kelas Belajar}

Kelas Belajar adalah wadah belajar mengajar bagi anggota guna meningkatkan pengetahuan, keterampilan dan sikap agar tumbuh dan berkembang menjadi usahatani yang mandiri sehingga dapat meningkatkan produktivitas, pendapatan serta kehidupan yang lebih baik. Rekapitulasi kemampuan kelompoktani di Kecamatan Raman Utara Kabupaten Lampung Timur dapat dilihat pada Tabel 2.

Berdasarkan pada Tabel 2 tampak bahwa kemampuan kelompoktani sebagai Kelas Belajar termasuk dalam kategori sedang. yang artinya Kemampuan kelompoktani sebagai kelas belajar berada pada kategori sedang. Hasil tersebut diketahui bahwa kemampuan kelompok tani sebagai kelas belajar cukup baik karena kelompok tani sudah merencanakan pertemuan kelompok dan dalam pemanfaatan suberdaya sebagai faktor produksi. Mereka selalu didampingi penyuluh dalam melaksanakan kegiatan sehingga dengan petunjuk penyuluh dapat mengurangi kerusakan lingkungan.

Pengurus kelompok sudah memotivasi anggota sehingga anggota disiplin terhadap aturan kelompok seperti: kehadiran pada pertemuan kelompok. Penyuluh dapat mengurangi kerusakan lingkungan. Sebagai kelas belajar, pengurus kelompok belum mampu mengkader anggota kelompok sebagai proses pembelajaran. Untuk mampu menjadi pengurus kelompok sehingga kelompok masih terpaku dengan individu tertentu untuk tetap menjabat sebagai pengurus kelompok. Apabila pengurus kelompok berhalangan hadir dalam kegiatan kelompok maka kegiatan kelompok tidak berjalan sehingga kegiatan pertemuan kelompok yang sudah dijadwalkan menjadi tertunda untuk dilaksanakan.

\section{B. Wahana Kerja sama}

Wahana kerjasama adalah kelompok tani sebagai tempat untuk memperkuat kerjasama baik antara sesama petani dalam poktan dan antar poktan maupun dengan pihak lain.

Tabel 2. Rekapitulasi kemampuan kelompoktani di Kecamatan Raman Utara Kabupaten Lampung Timur.

\begin{tabular}{clcc}
\hline No & \multicolumn{1}{c}{ Variabel } & $\begin{array}{c}\text { Rata-rata } \\
\text { skor }\end{array}$ & Kategori \\
\hline 1. & Kelas Belajar & 18,38 & Sedang \\
2. Wahana Kerjasama & 16,57 & Sedang \\
3. $\quad$ Unit Produksi & 14,50 & Sedang \\
\hline Jumlah & 49,46 & \\
\hline \multicolumn{2}{l}{ Rata-rata } & 16,48 & Sedang \\
\hline Sumber : Data Primer, 2017 & &
\end{tabular}


Melalui kerjasama ini diharapkan usahatani lebih efisien dan lebih mampu menghadapi ancaman, tantangan, hambatan, gangguan serta lebih menguntungkan.

Berdasarkan pada Tabel 2 tampak bahwa kemampuan kelompoktani sebagai wahana kerja sama termasuk dalam kategori sedang. Menunjukkan bahwa kemampuan kelompok tani wahana kerjasama kelompok tanicukup baik dalam berpartisipasi program pelestarian lingkungan seperti: "evojia" (penanaman inang, bunga-bunga, dan pemberantasan hama) serta anggota ikut berpartisipasi yang diprogramkan oleh pemerintah seperti kegiatan bakti sosial dan penghijauan, anggota berpartisipasi dalam mengembangkan aturan kelompok dan mentaati aturan atau kesepakatan yang telah disusun didalam kelompok secara disiplin dengan melakukan pembagian tugas antara sesama anggota. Pengurus kelompok sudah berfungsi cukup baik dalam melakukan kerjasama antara sesama anggota akan tetapi, masih kurang mampu dalam mengembangkan kepemimpinan untuk menjadikan kelompok sebagai wahana kerja sama.

\section{Unit Produksi}

Unit produksi adalah Usahatani yang dilaksanakan oleh masing-masing anggota poktan secara keseluruhan harus dipandang sebagai satu kesatuan usaha yang dapat dikembangkan untuk mencapai skala ekonomis usaha, dengan menjaga kuantitas, kualitas maupun kontinuitas.

Berdasarkan pada Tabel 2 tampak bahwa kemampuan kelompoktani sebagai Unit Produksi termasuk dalam kategori sedang. menunjukkan Unit produksi sudah cukup dikembangkan oleh anggota karena pembagian tugas diantara anggota kelompok baik pengurus maupun anggota sudah cukup berjalan sebagaimana tujuan utama kelompok. Namun dalam konteks unit produksi dalam skala individu (skala rumah tangga) unit produksi masih tergolong rendah karena keterbatasan modal yang dimiliki dan adanya usaha perorangan/individu dari anggota. Hal tersebut menyebabkan kelompok masih belum mampu melakukan pemupukan modal untuk membeli faktor produksi yang dibutuhkan dan digunakan untuk unit usaha kelompok.

\section{Hasil Pengujian Hipotesis}

Analisis hubungan antara variabel $\mathrm{X}$ (kompetensi PPL) dengan variabel Y (kemampuan kelompok tani ) dalam penelitian ini menggunakan statistika nonparametrik uji korelasi Kruskal wallis dengan bantuan SPSS 16. Hasil pengujian statistik terhadap hubungan kompetensi PPL dan kelompoktani. Hasil pengujian menggunakan SPSS 16.0 menunjukkan bahwa nilai signifikasi sebesar 0,000. Nilai hasil tes statistik sebesar 0,000 lebih kecil dibandingkan tingkat kepercayaan $95 \% \quad(\alpha=0,05)$ yang berarti menerima $\mathrm{H}_{1}$ yaitu bahwa terdapat hubungan kompetensi PPL dan kemampuan kelompok tani dalam menunjang BP3K Berprestasi artinya kompetensi PPL mempunyai hubungan dengan kemampuan kelompok tani dalam menunjang BP3K Berprestasi dapat dilihat Nilai $\mathrm{H}$ pada Tabel 4 menunjukkan rata-rata masing-masing perlakuan, Hasil pengujian statistik kruskals wallis dengan menggunakan SPSS 16.0 menunjukkan bahwa nilai signifikasi sebesar 0,000 . Nilai hasil tes statistik sebesar 0,000 lebih kecil dibandingkan tingkat kepercayaan $95 \%(\alpha=0,05)$ yang berarti menerima $\mathrm{H}_{1}$ yang artinya Kompetensi PPL mempunyai hubungan dengan kemampuan kelompok tani dalam menunjang BP3K Berprestasi di Kecamatan Raman Utara Kabupaten Lampung Timur.

\section{KESIMPULAN}

Kompetensi PPL di Kecamatan Raman Utara termasuk dalam kategori sedang. Hal ini dapat dilihat pada indikator kompetensi administrasi, pelaksanaan program, komunikasi, pemahaman perilaku manusia, memelihara profesionalisme, perencanaan program, pengajaran, evaluasi yang sebagian besar termasuk dalam kategori sedang.

Kemampuan kelompok tani yang dimiliki petani termasuk kedalam kategori sedang, hal ini ditunjukkan pada indikator kemampuan kelompoktani sebagai kelas belajar, wahana kerja sama, dan unit produksi sudah berjalan dengan cukup baik. Terdapat hubungan antara kompetensi PPL dengan kemampuan kelompoktani dalam menujang BP3K Berprestasi di Kecamatan Raman Utara.

\section{DAFTAR PUSTAKA}

Handayani F, Sutadji, dan Margono. 2015. Analisis persepsi petani terhadap kompetensi penyuluh pertanian lapangan dalam pembangunan pertanian di Kabupaten Kutai Timur. Jurnal Administrasi, Vol 3 (2) 279-280. http://ar.m ian.fisip-unmul.ac.id/site/wp-content/uploads/ 2015/05/jurnal\%20an.\%20furry\%20\%2805-1 9-15-01-37-49\%29.pdf. [ 28 Januari 2017]. 
Imran dan Ganang. 1999. Menggugah profesionalitas dan etika bisnis. Majalah Manajemen No 129. Jakarta .

Kartasapoetra AG. 1994. Teknologi Penyuluhan Pertanian. Bina Aksara. Jakarta.

Kementerian Pertanian. 2013. Peraturan Menteri Pertanian Nomor 82/Permentan/OT. 140/8/2013 Tentang Pedoman Pembinaan Kelompok Tani dan Gabungan Kelompok Tani. Kementan. Jakarta.

2014. Kebijakan pembangunan pertanian 2015-2019. http://www.pertanian.go.id/eplanning/tinymcp uk/gambar/file/Kebijakan_pembangunan_per tanian_2015-2019.pdf. [02 Oktober 2015].

Mangkuprawira, S. 2004. Arti dan Beragam Aspek tentang Kompetensi. Makalah penunjang untuk lokakarya Fakultas Pertanian. IPB. Bogor.

Sari AD, Nikmatullah D, dan Silvianti S. 2018. Kinerja penyuluh pertanian lapangan dalam melaksanakan tugas pokok penyuluh di BP3K Kecamatan Banjar Baru Kabupaten Tulang Bawang. JIIA, 5 (4) : 442. http://jurnal.fp. unila.ac.id/index.php/JIA/article/view/1754/1 557. [5 MEI 2018].

Santi, Nikmatullah D, dan Tedi RT. 2016. Tingkat kinerja penyuluh pertanian tanaman pangan di BP3K Kecamatan Gadingrejo Kabupaten Pringsewu JIIA, Vol 4 (3) 309-316. http:// jurnal.fp.unila.ac.id/index.php/JIA/artice/view /1506/1360. [ 5 Mei 2018]

Siegel S. 1986. Statistik Non-Parametrik Ilmuilmu Sosial. PT Gramedia Pustaka Utama. Jakarta.

Sitompul A. 2014. Alasan Diperlukan Perencanaan Program Penyuluhan.

Sugiarto D, Siagian, Sunaryanto, dan Oetomo 2003. Teknik Sampling. PT. Gramedia Pustaka Utama. Jakarta. 